\title{
Rationalizing Job Satisfaction: A Empirical Study among College Teachers in Private Sector of Pakistan
}

\author{
Nasir Mahmood ${ }^{* 1}$, Cai Jianfeng ${ }^{1}$, Hina Munir ${ }^{1}$, Farhan Jamil ${ }^{2}$ \\ ${ }^{1}$ School of Management, Northwestern Polytechnical University, Xi'an, 710072 Shannxi, P.R. \\ China \\ ${ }^{2}$ Department of Management, Universiti Teknologi Malaysia, 81310, Malaysia \\ *nasirmahmood@mail.nwpu.edu.cn
}

\begin{abstract}
Keywords; Job Satisfaction, Service industry, Private Sector College Teachers, Pakistan
Abstract-: The profession of teaching is one of most stressful profession all over the world. The current study intends to examine the job satisfaction among the Private college teachers (Male and Female) in Pakistan. A questionnaire based descriptive type research design was adopted in the current study. The current study considered the faculty of Private colleges in city of Lahore, for this purpose of data collection multiple mode were selected such as email, in person and by post, 250 questionnaire were distributed out of which 150 questionnaires were useful for the study which shows the response rate of 60\%. For the purpose of the analysis SPSS 19.00 was used. The results of the study showed the demographic analysis and correlation analysis which shows the significant relation among all the job satisfaction dimensions. Based on the findings of the current study to improve the job satisfaction in private college teachers the academic administrators should focus on its different dimensions specially on supervision, rewards and working environment for females to improve the level of job satisfaction.
\end{abstract}

\section{Introduction}

The teaching is one of most respectable profession and plays a vital role in development of societies. The teachers help students to acquire knowledge, information for their development and to shoulder the responsibility of taking the nation towards development, therefore the teachers are considered as the pillars of the society [1]. The need of every teacher is independence, recognition, security and new experience. Needs are important for everyone, if the needs of teachers are not met, the unrest and dissatisfaction among teachers is increased which is very unhealthy for not only teachers but also for students. The job is a vital component of life and also a main source of income [2]. The job of a teacher requires a major part of day and is also a source of contribution in the society; hence the satisfaction of job is necessary for a teacher as well as overall wellbeing [3-4]. The relationship of job dissatisfaction and satisfaction depends upon what one expects and obtains from one's job. The ability to meet the needs of teachers and improve the performance is the job satisfaction and when one is satisfied from the job, the competencies, skills and knowledge is reflected from one's behavior. Therefore, the job satisfaction is very important for productive activities in the college as well as for the growth of any educational system in the world. A study conducted on effects of gender on organizational commitment and job satisfaction by Suki (2011) disclosed that there is no significance effect on perception of job satisfaction among male and female teachers [5]. However, Kumar \& Bhatia (2011) in their study observed that the attitude and job satisfaction in physical education teachers is least affected by marital status, gender, income and minimum qualification [6]. Another study conducted by Zilli and Zahoor (2012) to compare the organizational commitment between male and female teachers of higher education, revealed that the female teaching staff have higher level of organizational commitment as compare to male teaching staff [7] . A descriptive study conducted by Mehta (2012) to find out the impact of type of organization (Private/Government) on School Teachers, concluded that the level of job satisfaction is affected by the type of organization and the teachers of government sector schools are more satisfied than private [8]. A research on "Organizational commitment and job satisfaction among teachers during times of Burnout for developing and test a model for Burnout and its effect on job 
satisfaction on organizational commitment" conducted by Nagar (2012) showed that the mean score for female teaching staff is higher than the male in terms of job satisfaction and organizational $\begin{array}{lllll}\text { commitment [9]. Job hatisfaction been } & \end{array}$

considered as an important subject all over the world as it is necessary for the growth of educational system and development of society in all over the world. In this context, the satisfaction of job is related to meeting the needs and demands of teacher's in-order to motivate and improve their skills as well as performance. The satisfaction is very important in all aspects of any profession; the occurrence of skills, knowledge \& competencies depends upon the satisfaction of behavior of individuals [10]. Therefore, the satisfaction of teachers of any college is needed in their behaviors so that they can perform their duties with commitment, dedication and hard work to provide latest knowledge and information to students for their development [11]. The aim of this study was to examine the level of job satisfaction and investigate the reasons of job stress in teachers of Private Colleges (Male \& Female).

\section{METHODOLOGY}

The current study aims at examining the level of job satisfaction among the teachers working in the private sector colleges located in Lahore, ( that is famous with the name of "city of colleges" in the world) Pakistan. The current study consists of descriptive research design. Five private colleges located in different area of the city were selected. These private colleges are making well contribution in providing of quality of education in society since last decade. The study has taken a period of Six months (July 2015 to December 2015). The questionnaire prepared to gauge the importance of various factors on job satisfaction. 250 questionnaires were distributed to 5 private college faculty members while adopting different method of communication which includes in person, via email, by post, out of which 150 questionnaires were useful for the study which shows the response rate of $60 \%$. The respondents of the study were lecturer, senior lecturer. To measure the level of job satisfaction and its dimensions which includes pay and promotion, rewards and recognition, relation with co-workers, working environment, work load, work itself, supervision, autonomy a survey consisted of five point likert scale was prepared. In questionnaire the demographics questions also asked from the respondents. Data was collected while adopting the convenience sampling technique. Data was analyzed in SPSS 19 and represents the demographic profile of the respondents and correlation analysis among the different dimensions of the job satisfaction.

\section{ANALYSIS}

The current study aims at examining the level of job satisfaction among the teachers working in the private sector colleges located in Lahore, Pakistan. The current study consists of descriptive research design. 250 questionnaires were distributed to 5 private college faculty members while adopting different method of communication which includes in person, via email, by post, out of which 150 questionnaires were useful for the study which shows the response rate of $60 \%$ To measure the level of job satisfaction and its dimensions which includes pay and promotion, rewards and recognition, relation with co-workers, working environment, work load, work itself, supervision, autonomy a survey consisted of five point likert scale was prepared. In questionnaire the demographics questions also asked from the respondents. Data was collected while adopting the convenience sampling technique. Data was analyzed in SPSS 19 and represents the demographic profile of the respondents and correlation analysis among the different dimensions of the job satisfaction. 
Table 1: Name of Colleges

\begin{tabular}{|l|l|l|}
\hline Sr no. & \multicolumn{1}{|c|}{ Name of College } & No. of respondents \\
\hline 1 & Punjab group of colleges & 50 \\
\hline 2 & Superior college & 24 \\
\hline 3 & Central group of colleges & 35 \\
\hline 4 & Scholar college & 20 \\
\hline 5 & Leadership colleges & 21 \\
\hline Total & & 150 \\
\hline
\end{tabular}

Table 2: Demographics of the Respondents

\begin{tabular}{|l|l|l|l|}
\hline $\begin{array}{c}\text { Demographic } \\
\text { Variable }\end{array}$ & Category & Frequency & Percent \\
\hline Gender & Male & 110 & \\
& Female & 40 & 73.00 \\
& Total & 150 & 27.00 \\
\hline Age & $18-25$ & 45 & 100.00 \\
\hline & $26-35$ & 70 & 30.00 \\
& Above 35 & 35 & 47.00 \\
& Total & 150 & 23.00 \\
Marital status & Married & 95 & 100.00 \\
& Single & 55 & 63.00 \\
& Total & 150 & 37.00 \\
\hline Qualification & Graduate & 25 & 100.00 \\
\hline level & Masters & 70 & 17.00 \\
& MPhil & 55 & 47.00 \\
& Total & 150 & 36.00 \\
Work & 1-5 years & 90 & 100.00 \\
Experience & 6-10years & 39 & 60.00 \\
& 11-15years & 15 & 26.00 \\
& More than 15 & 6 & 10.00 \\
& years & & 4.00 \\
& Total & 150 & 100.00 \\
\hline
\end{tabular}

Table 3: Mean, Correlation

\begin{tabular}{|c|c|c|c|c|c|c|c|c|c|}
\hline VAR & Mean & 1 & 2 & 3 & 4 & 5 & 6 & 7 & 8 \\
\hline$P \& P$ & 2.541 & 1 & & & & & & & \\
\hline $\mathrm{R} \& \mathrm{R}$ & 2.672 & $.262 * *$ & 1 & & & & & & \\
\hline RCW & 3.014 & $.055^{* *}$ & $.148 * *$ & 1 & & & & & \\
\hline WE & 3.045 & $.499 * *$ & $.311 * *$ & $.403 * *$ & 1 & & & & \\
\hline WL & 3.450 & $.419 * *$ & $.298 * *$ & $.097 * *$ & $.543 * *$ & 1 & & & \\
\hline WIS & 2.101 & $.657 * *$ & $.382 * *$ & -.062 & $.402 * *$ & $.376^{* *}$ & 1 & & \\
\hline SS & 3.910 & $.521 * *$ & $.174 * *$ & $.126^{* *}$ & $.107 * *$ & $.214 * *$ & $.484 * *$ & 1 & \\
\hline Aut & 2.672 & $.275^{*}$ & $.341 * *$ & $.290 * *$ & $.072 *$ & $.198 *$ & $.586^{* *}$ & $.171^{*}$ & 1 \\
\hline
\end{tabular}

*. Correlation is significant at the 0.05 level (2-tailed). **. Correlation is significant at the 0.01 level (2-tailed).

- Variable, Pay \&Promotion*, Rewards \&Recognition*, Relation with co-worker* Working Environment*, Work load*, Work itself*, Supervisor Support*, Autonomy* 
Table 4: Overall level of Teachers Satisfaction

\begin{tabular}{|l|l|}
\hline \multicolumn{1}{|c|}{ Responses } & \multicolumn{1}{c|}{ Number of Respondents } \\
\hline Highly Satisfied & 20 \\
\hline Satisfied & 50 \\
\hline Neutral & 50 \\
\hline Dissatisfied & 20 \\
\hline Highly Dissatisfied & 10 \\
\hline
\end{tabular}

Fig.1

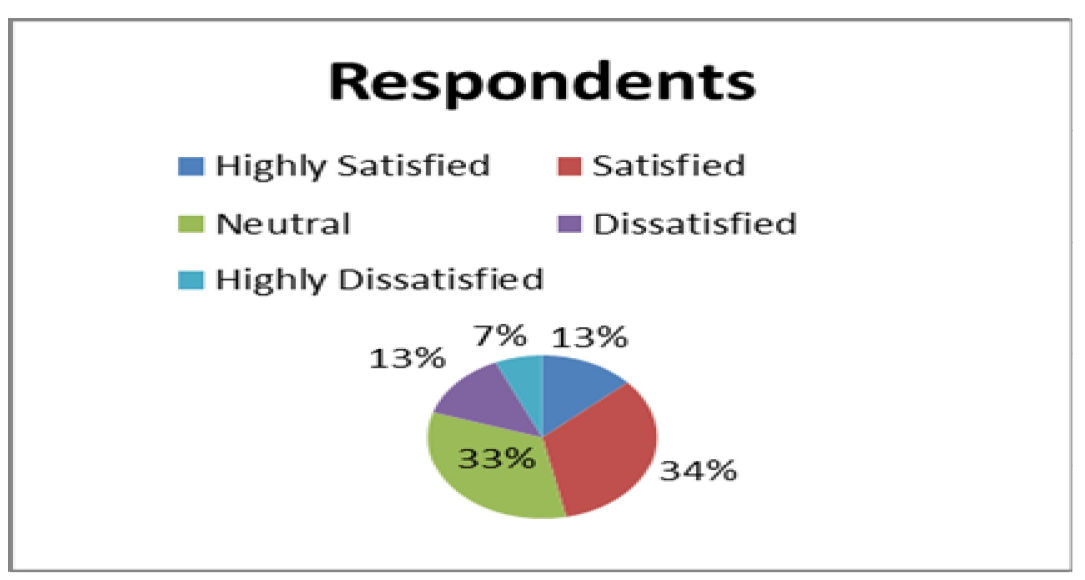

\section{FINDINGS}

The findings offer a better understanding about job satisfaction of teachers. The research study enhance relationship of teachers job satisfaction among P\&P, R\&R, RCW, WE, WL,WIS,SS and AUT. The job satisfaction is one of important element of teaching profession; the job satisfaction of Teacher is directly proportional to the performance and effectiveness of the College. From this limited study, it is found that there are varieties of factors which affect teachers' job satisfaction. These factors include non-availability of accommodation, stumpy salary, working environment, lengthy procedures to follow rules and regulations of the job, and class room activities, behavior and attitude of superiors; freedom for participating in decision making, recognition of the society. The above factors have great effects on the satisfaction level of teachers. The job satisfactions among male and female teachers have a high degree of positive correlation and there is also a positive correlation between the years of service and job satisfaction of college teachers. The teachers should be provided better training methods, restroom facilities and also training to overcome the stress during job. There should be a better relationship with administrative authorities and teaching staff; they should be involved while making any policy decision at higher levels for attaining higher satisfaction from all such aspects of their profession.

\section{CONCLUSION}

Due to stumpy salary, delay in promotion, non-availability of accommodation, lack of appropriate facilities in the colleges and work life imbalance almost half of the teaching staff was dissatisfied with their jobs. Improper planning for appointment/posting of teaching staff was also found as a vital issue in the present study. Considering the results of the study, it is proposed that the pay \& promotion policy should be reviewed and accommodation with sufficient facilities should be offered to the teaching staff in-order to motivate them. 


\section{RECOMMENDATION}

The college teaching staff should be provided sufficient trainings to update their knowledge improve their performance and face the challenges \& stress during job. The teaching staff should also be provided latest training methods for improvement of their performance and there should also be a better relationship with administrative authorities; the teaching staff may also be given sufficient freedom for decision making in their teachings for attaining higher satisfaction level. The workshops may also be organized from time to time in-order to up-date the knowledge of teaching staff, acquire latest teaching techniques and also to make work life balance. Moreover, the higher authorities should also focus to adopt the international standards in appointment/posting of teaching staff and should also maintain the pupil-teacher ratio so that the workload of teaching staff should be maintained and the quality education should be provided to the students.

\section{LIMITATION OF THE STUDY}

Job satisfaction is a very vital concern in every field, so enormous area can be studied for such type of research. The present study is limited to only one district; the same can be extended to overall province/country. Research on job satisfaction can be completed by not only taking data from the school teachers but also taking information from university teachers as well as from the employees of other sectors/ departments.

\section{ACKNOWLEDGEMENT}

The authors are thankful to Northwestern Polytechnical University, NPU, Xi'an, and National Natural Science Foundation of China under Grant No. 2014JM9368.

\section{References}

[1] Ahsan, Nilufar, Zaini Abdulla, David Yong Gin Fie and Syed Shah Alam (2009). "A Study on Job Satisfaction among University Staff in Malaysia: An Empirical Study". European Journal of Social Science, 8(1):121 - 131.

[2] George, Evy, Daniel Louw and Gerhard Badenhorst (2008). "Job Satisfaction among Urban Secondary School teachers", South African Journal of Education 28(2):135-154.

[3] Thakira Khatoon (2000). Job Satisfaction of Secondary School Teachers in relation to their personnel variables: Sex, Experience, Professional Training, Salary and Religion. Journal of Indian Educational Review, 36(1).

[4] Natarajan, R. (2001). A study on School Organizational climate and Job Satisfaction of Teachers. Journal of Educational Research and Extension, 38-4.

[5] Suki, N., \& Suki, N. (2011). Job Satisfaction and Organizational Commitment: The Effect of Gender. International journal of psychology research, 6(5), 1-15.

[6] Kumari, S., \& Jafri, S. (2011). „Level of Organizational Commitment of Male and Female Teachers of Secondary Schools $\square$. Journal of Community Guidance \& Research, 28(1), 37-47.

[7] Zilli, A. S., \& Zahoor, Z. (2012). Organizational Commitment among Male and Female

[8] Higher Education Teachers. Indian Journal of Psychology and Education, 2(1), 55-60.

[9] Mehta, D. S. (2012). „Job Satisfaction among Teachers $\square$. International Journal of Research in Commerce IT \& Management, 2(4), 77-83.

[10]Nagar, k. (2012, April). „Organizational commitment and job satisfaction among teachers during times of Burnout $\square$. Vikalpa, 37.2, 43-60. 
[11] Shared Kumar and Sabita P. Patnaik (2002). A Study of organizational Commitment, attitude towards work and Job Satisfaction of post graduate teachers of Goa. Journal of Educational

Research and

Extension,

39.1. 